\title{
Investigar, processar e punir: um tribunal de exceção ou a Comissão de Investigação Sumária - 1964 ${ }^{1}$
}

\begin{abstract}
Resumo
As formas de investigar, processar e punir são tecidas nas disputas políticas das relações de poder em que são forjadas. Nesse sentido, os procedimentos de atuação da Comissão de Investigação Sumária, adquiriram maneiras específicas de atuar e de produzir efeitos para os inquéritos por ela movidos. Este artigo analisa as ações da Comissão de Investigação Sumária aberta em abril de 1964 para investigar, processar e punir as pessoas envolvidas com o que foi considerado subversão comunista no Brasil nos primeiros meses da ditadura militar de 1964. Foca a análise nos documentos oficiais que regulamentaram as atividades da referida Comissão e nos inquéritos por ela movidos contra lideranças políticas de esquerda atuantes no Estado de Pernambuco, demonstrando as práticas de exceção que a ditadura militar instituiu para investigar, processar e condenar sumariamente seus opositores políticos.
\end{abstract}

\section{Erinaldo Vicente Cavalcanti}

Doutor em História pela Universidade Federal de Pernambuco (UFPE). Professor do Programa de Pós-Graduçaõ em História da Universidade Federal do Sul e Sudeste do Pará (Unifesspa). Marabá, PA - Brasil

ericontadordehistorias@gmail.com https://orcid.org/0000-0002-9912-5713

Palavras-chave: Ditadura Militar. Repressão.

Punição. Condenação.

\section{Para citar este artigo:}

CAVALCANTI, Erinaldo Vicente. Investigar, processar e punir: um tribunal de exceção ou a Comissão de Investigação Sumária - 1964. Tempo e Argumento, Florianópolis, v. 11, n. 28, p. 445 - 468, set./dez. 2019.

\section{DOI: $10.5965 / 2175180311282019445$}

http://dx.doi.org/10.5965/2175180311282019445

\footnotetext{
1 Este texto faz parte das pesquisas que desenvolvo acerca da ditadura militar no Brasil. Uma parte da documentação foi mobilizada durante a realização da tese de doutorado defendida em 2015 no Programa de Pós-Graduação em História da UFPE. Uma versão condensada da tese foi publicada resultando no livro Ditadura militar no Brasil: entre práticas e representações (1960-1968). Rio de Janeiro e Recife: FGV e EdUFPE, 2017.
} 
Investigate, process and

punish: a court of exception

or the Summary Investigation

Commission (1964)

\begin{abstract}
The ways of investigating, processing, and punishing are built on political disputes where they are elaborated. In this sense, the action procedures of the Summary Investigation Commission had acquired specific ways of acting and having effects on the investigations which were conducted. This article analyzes the work of the Summary Investigation Commission opened in April of 1964 to investigate, prosecute, and punish the people involved with what was considered communist subversion in Brazil in the first months of the military dictatorship of 1964. It focuses the analysis on the official documents that regulate the activities of the said Commission and on the inquiries it had made against leftist political leaders in the State of Pernambuco, demonstrating the exceptional practices that the military dictatorship instituted to investigate, prosecute, and summarily condemn its political opponents.
\end{abstract}

Keywords: Military Dictatorship. Repression.

Punishment. Conviction.

\title{
A criação da Comissão de Investigação Sumária
}

Em julho de 1969, o Ministério da Aeronáutica publicou um dossiê intitulado Atos da Revolução de $1964^{2}$. Segundo o dossiê, foi com o objetivo de possibilitar a aplicação do que versava o Ato Institucional de 9 de abril de 1964 - denominado posteriormente de Al1 - que foram criadas as Comissões de Investigação e, posteriormente, instaurados os Inquéritos Policial Militar (IPM) em todos os Estados. Para tanto, era fundamental a cooperação entre os ministérios civis e militares para possibilitar o conhecimento acerca dos cidadãos punidos e afastados das funções nos setores da administração pública.

\footnotetext{
${ }^{2}$ Ministério da Aeronáutica. Atos da Revolução de 1964. SNI/ASP/ACE. ARQUIVO NACIONAL - BRASíLIA. Número de identificação ASP_ACE_2860_80_001.
} 
Por meio do Decreto 53.897, de 27 de abril de 1964, Castelo Branco criou a Comissão Geral de Investigação (CGI) para promover a investigação sumária a que se referia o artigo $7^{\circ}$ do Al-1 (BRASIL, 1964). O referido decreto instituía a Comissão Geral de Investigação e, dela, as Comissões de Investigação Sumária nos Estados. O artigo do Al-1 discorria sobre a cassação e a suspensão das garantias constitucionais ou legais de vitaliciedade e estabilidade daqueles que tivessem atentado contra "a segurança do País, o regime democrático e a probidade da Administração Pública (BRASIL, 1964, p.4)”.

Conforme destaca Paulo Giovani Antonino Nunes,

Castelo Branco, através de decreto-lei institui os IPMs, já previstos no Al1, dando início a chamada "Operação Limpeza". Os referidos Inquéritos deveriam investigar as atividades de funcionários civis e militares, de níveis municipal, estadual e federal, para identificar os que estavam comprometidos em atividades "subversivas". (NUNES, 2013, p. 02)

Portanto, no primeiro mês do governo ditatorial, foi promulgado o $\mathrm{Al}-1$, instituindo a base legal para criar a CGI e, com elas, as Comissões de Investigação Sumária para investigar, processar e punir os servidores públicos - e demais cidadãos - que fossem considerados ameaça à segurança do país.

Sob o comando de Castelo Branco, os inquéritos da Comissão de Investigação Sumária3 iniciam oficialmente as cassações no regime ditatorial sustentadas em um conjunto de leis que Ihes atribuíam efeitos de legitimidade. Na análise do historiador Carlos Fico, coube a Castelo Branco

[...] tornar legal a noção de "guerra interna" e permitir que brasileiros civis fossem indiscriminadamente acusados de subversivos - base jurídica e conceitual indispensável para que a linha dura passasse da simples condição de grupo de pressão para a perigosa posição de "sistema de segurança" com permissão para investigar, prender e interrogar, erigindo-se em polícia política. (FICO, 2001, p. 56)

\footnotetext{
3 Em alguns momentos usarei a sigla CIS para me referir à Comissão de Investigação Sumária e PI para Prontuário Individual. No entanto, essas siglas não aparecem em nenhum dos documentos pesquisados; a menção é sempre por extenso. Os inquéritos movidos pela comissão aos quais tive acesso para pesquisa encontram-se no Arquivo Público do Estado de Pernambuco Jordão Emerenciano no Fundo SSP/DOPS/APEJE.
} 
Se Castelo Branco foi responsável por intensificar as ações que indiscriminadamente acusavam brasileiros de subversivos, elas já estavam em execução por meio da Lei de Segurança Nacional (BRASIL, 1953), principalmente com a reformulação do texto em 1953. A LSN de 1953 foi o dispositivo legal usado para justificar e legitimar as mais diversas práticas repressivas durante os três primeiros anos do regime militar, conforme aparece de forma recorrente na documentação pesquisada ${ }^{4}$. O recurso àquele dispositivo também concorria para atribuir legitimidade às práticas desenvolvidas no governo ditatorial e, como demonstrou Rezende (2013), este foi um dos objetivos posto em prática pelo regime militar. As sanções decretadas pela Comissão de Investigação Sumária, nos meses subsequentes à implantação da ditadura, por exemplo, foram legitimadas por meio dos artigos dessa lei.

As Comissões de Investigação Sumária ficavam subordinadas diretamente à Comissão Geral de Investigação. No entanto, seus trabalhos eram executados pela Secretaria de Segurança Pública do Estado em estreita parceria com o Exército e a Aeronáutica, como podemos observar no Dossiê Atos da Revolução e, principalmente, na documentação arrolada nos inquéritos localizados. Ao menos no Estado de Pernambuco, os trabalhos da Comissão seguiram esses procedimentos 5 . Conforme os registros disponíveis nos inquéritos, as Comissões eram compostas por três membros, entre servidores civis e militares. Mas também poderiam fazer parte profissionais liberais, desde que tivessem reconhecida idoneidade e assim fossem considerados pelo Presidente da República, que também escolhia o presidente de cada Comissão.

As Comissões eram responsáveis por todo o processo constitutivo dos inquéritos. Da abertura, instituída por Portaria, passando pela Atuação, pelos Termos de Compromissos, Termos de Declaração, emissão das Declarações, Auto de Interrogatório, Conclusão, Despacho, até a sentença emitida nos dois Relatórios Finais. Um relatório era

\footnotetext{
${ }^{4}$ A Lei de Segurança Nacional aparece como o referente legal em todos os documentos resultantes das atividades da Comissão de Investigação Sumária. Os agentes responsáveis pela produção dos documentos mencionam os artigos da LSN como princípio jurídico e fundamento legítimo para explicar, justificar e emitir suas sentenças. Nos documentos pesquisados, a Lei de Segurança Nacional continuou sendo usada como dispositivo político de legitimação das ações repressivas movidas durante todo o regime ditatorial.

${ }^{5}$ Em virtude da ausência de trabalhos que analisem os documentos da Comissão de Investigação Sumária, não temos como saber, por enquanto, se foi esse o procedimento adotado em outros estados.
} 
emitido quando se concluíam os trabalhos da Comissão nos respectivos municípios onde ocorriam as investigações. Em Recife, eram lavrados o Recebimento, a Juntada e a Remessa, quando os autos dos inquéritos chegavam à sede da Comissão ${ }^{6}$. Dias depois, era lavrado outro relatório, este de caráter final e conclusivo do inquérito.

É oportuno ressaltar que praticamente não dispomos de pesquisas que se dedicam à análise dos documentos resultantes das atividades das Comissões de Investigação Sumária. Há pesquisas e bibliografia sobre os Inquéritos Policiais Militares (IPMs) que começam a ser desenvolvidos alguns dias após o início dos trabalhos das comissões. Deve-se ainda registrar que, parte da base documental que abasteceu os IPMs, é resultante dos registros produzidos pelas referidas comissões, conforme se percebe nos inquéritos que localizei no Arquivo Público de Pernambuco.

Localizei, no acervo DOPS-PE, do Arquivo Público de Pernambuco Jordão Emerenciano, cópias de doze inquéritos movidos pela Comissão de Investigação Sumária contra cidadãos civis que residiam no município de Caruaru.

No início da década de 1960, o município de Caruaru - localizado a 130 quilômetros de Recife - aparece nos anuários do Instituto Brasileiro de Geografia e Estatística - IBGE como o terceiro mais populoso do estado com 109.996 habitantes e predominantemente católico. Ocupava também a segunda posição no estado, em números de votantes e era o segundo maior colégio eleitoral.

\footnotetext{
${ }^{6}$ Respectivamente, "Portaria", documento lavrado com número de identificação do processo. "Atuação", documento registrando a ação inicial dos trabalhos datada do registro oficial por meio da portaria lavrada anteriormente. "Termos de compromissos", documento com a nomeação do presidente e do escrivão que atuarão no respectivo inquérito seguindo a assinatura do termo de compromisso para o desempenho das funções a serem executadas. "Termos de Declaração", documento que consistia nas declarações prestadas pelas testemunhas convocadas pela Comissão. "Declarações", documento lavrado pelo escrivão usando a citação de algum depoimento, quando este fazia referência ao acusado no inquérito em procedimento. "Auto de Interrogatório", documento lavrado com os depoimentos dos acusados em cada inquérito. "Conclusão". Como o próprio nome sugere, trata-se do momento de conclusão da emissão das provas, antes de os relatórios serem lavrados. "Despacho". Trata-se do procedimento da junção de outros documentos ao referido inquérito, também executado na mesma data em que é lavrada a conclusão. "Relatório final". Os relatórios consistem na síntese do inquérito e na sentença interpretativa do promotor que presidiu a Comissão. "Recebimento". Trata-se do registro oficial do recebimento do material na sede da Secretaria em Recife. "Juntada". Registro da confirmação de que os autos constantes no inquérito foram devidamente juntados pelo escrivão. "Remessa". Registro oficializando o envio dos autos ao secretário de Segurança Pública. Esses documentos encontram-se disponíveis no Arquivo Público do Estado de Pernambuco Jordão Emerenciano no Fundo SSP/DOPS/APEJE.
} 
O anticomunismo na década de 1960 foi pauta dos principais enfrentamentos políticos no Brasil, como demonstrou Rodrigo Patto Sá Motta (2002, 2006 e 2014). A narrativa que instituía o comunismo como um grande perigo e inimigo a ser combatido também é identificada inclusive nos relatos de memória de muitos militares, como mostrou Celina d'Araujo (1994a 1994b). Em Pernambuco, o discurso de que o comunismo representava uma grande ameaça e, portanto precisa ser combatido, foi um dos principais argumentos usados pela secretaria de segurança pública para vigiar, perseguir, prender e torturar diversos cidadãos civis que eram denominados de subversivos como demonstram as pesquisas de Antônio Montenegro (2003, 2010 e 2012), Pablo Porfírio (2009) e Erinaldo Cavalcanti (2017).

Esses enfrentamentos também foram experienciados no município de Caruaru. Com o discurso de combate ao comunismo, muitas pessoas foram delatadas. Cidadãos civis foram fichados, vigiados e perseguidos. Dezenas de pessoas foram denunciadas, investigadas, processadas e torturadas. A documentação dos jornais 7 , dos relatos de memória ${ }^{8}$, do DOPS-PE, dos órgãos de segurança e informação e, sobretudo, da Comissão de Investigação Sumária - sobre Pernambuco e Caruaru, em específico - permite analisar e compreender as práticas de vigilância, perseguição, prisão, torturas e condenações sumárias perpetradas pelo regime militar instaurado em abril de 1964.

A Comissão de Investigação Sumária em Caruaru foi oficialmente aberta no dia 24 de abril de 1964, por meio da Portaria 277, na sede da Secretaria de Segurança Pública, em Recife, conforme consta nos doze inquéritos que localizei. Por essa informação, percebese que os trabalhos de investigação dos inquéritos após o golpe de 31 de março de 1964 estavam sendo desenvolvidos antes da criação oficial da CGI, que regulamentaria os inquéritos de investigação contra aqueles considerados subversivos. Ou seja, três dias antes de o Decreto 53.897 ser sancionado por Castelo Branco, em 27 de abril de 1964, a Secretaria de Segurança de Pernambuco já estava efetuando as diligências sobre os processos abertos em Caruaru.

\footnotetext{
7 Diario de Pernambuco; Jornal do Commercio; A Vanguarda; A Defesa e A Voz do Agreste.

${ }^{8}$ Relatos de memória produzidos através das entrevistas com Manoel Messias, Francisco de Assis Claudino e Romero de Figueiredo.
} 
Conforme demonstrou a pesquisadora Marcília Gama (2014), o Departamento de Ordem Política e Social - DOPS/PE se encarregou de desenvolver um conjunto de ações que envolvia a produção e circulação da informação, a vigilância e a repressão como política oficial de Estado, concorrendo para a construção do estado de exceção no Brasil. A Secretaria de Segurança Pública não esperou que o ditador Castelo Branco institucionalizasse a abertura dos inquéritos contra aqueles considerados uma ameaça à segurança do país. Por conseguinte, a abertura e a execução dos processos demonstram ainda que a Comissão de Investigação Sumária deu início oficialmente aos inquéritos de investigação contra os militantes das esquerdas na ditadura militar no Brasil. A Secretaria de Segurança Pública, portanto, inaugura a política repressiva de investigação no regime ditatorial instaurado em 1964 e, como já mencionado, após a criação da CGI, os inquéritos de investigação sumária continuaram sendo desenvolvidos por essa Secretaria.

A Comissão de Inquéritos designada para Caruaru foi composta pelo promotor Valter Rodrigues da Rosa Borges, como presidente, pelo major Luiz Silva Leal, como membro, e pelo $2^{\circ}$ Sargento Carlos da Rocha e Silva, como escrivão. Eles se deslocaram até Caruaru e, em parceira com o Exército, através da $22^{\mathrm{a}}$ Circunscrição de Recrutamento, realizaram as sindicâncias necessárias para a apuração dos inquéritos abertos contra diversos cidadãos considerados ameaça à segurança do país. Nesse sentido, produziram provas para os inquéritos, convocaram e ouviram inúmeras testemunhas, colheram os depoimentos dos investigados e lavraram os relatórios com as conclusões acusatórias.

De acordo com a legislação que regia os trabalhos da $\mathrm{CGI}$, os inquéritos de investigação seriam instaurados atendendo a diversas possibilidades. Poderiam ser abertos por iniciativa da própria Comissão ou mediante determinação do Presidente da República, dos Ministros de Estado, dos chefes dos Gabinetes Civil e Militar da Presidência da República e dos chefes dos Ministérios. Também poderiam ser instaurados inquéritos, por meio da representação dos dirigentes de autarquias, sociedades de economia mista, fundações e empresas públicas, haja vista que os trabalhos das Comissões também se destinavam aos funcionários públicos que, segundo suas concepções, tinham atentado contra a segurança do país e afastá-los de suas funções. 
A Comissão de Investigação Sumária tinha ainda autonomia para abrir processos de "investigação na órbita estadual e municipal sem prejuízo da competência dos governadores e prefeitos na resolução final do caso" (BRASIL, 1969, p. 11, artigo 3.). De acordo com o artigo $6^{\circ}$ do Decreto 53.897, quando os investigados fossem servidores públicos, após o encerramento das investigações, se a Comissão decidisse pela aplicação de alguma das sanções previstas no artigo $7^{\circ}$ do $\mathrm{Al}-1$, encaminharia o processo ao Ministério ou repartição em que estivesse lotado o servidor. Segundo esse artigo, os servidores que atentassem contra a segurança do país perderiam por seis meses seus direitos constitucionais ou legais de vitaliciedade e estabilidade. E eram os parâmetros estabelecidos na Lei de Segurança Nacional de 1953 que definiam a ações consideradas ameaça à segurança do país.

Nesses termos, a Comissão de Investigação Sumária ficava encarregada de aplicar o que versava o artigo $7^{\circ}$ do Ato Institucional de 9 de abril de 1964, abrindo inquéritos para investigar e processar aqueles que tivessem atentado contra a segurança do país, e assim, afastá-los da administração pública, pois era principalmente contra os servidores que deviam se direcionar os trabalhos da Comissão.

\section{A Comissão de Investigação Sumária e as disputas nas relações de poder local}

As Comissões de Investigação Sumária alteraram sensivelmente as relações de forças envolvendo os poderes Executivos e Legislativos nos espaços em que atuaram. Para os servidores públicos investigados pela Comissão que fossem funcionários municipais, caberia aos governadores sancionarem as penas mediante proposta do prefeito. Esse dispositivo era bem significativo, porque colocava no campo das relações em torno dos trabalhos da Comissão o poder exercido pelos executivos municipais. Em outros termos, os prefeitos eram acionados como sujeitos partícipes dos processos movidos pela Comissão contra seus funcionários acusados de subversão. Apenas mediante apresentação formal da chefia do executivo municipal, os governadores poderiam sancionar as medidas punitivas decretadas pela Comissão, quando os investigados fossem servidores municipais, conforme exposto no $\S 2^{\circ}$ do artigo $7^{\circ}$ do Ato Institucional $n^{\circ} 1$. 
Nesse sentido, era de fundamental importância que os prefeitos estivessem em sintonia com as propostas políticas defendidas pelos militares. Essa interpretação ajuda a compreender os expurgos que os chefes dos executivos - municipal e estadual sofreram quando se colocaram em posições contrárias àquelas defendidas pelo regime ditatorial. Desfrutar do apoio - mesmo que parcial e momentâneo - das lideranças locais poderia se instituir como importante mecanismo de legitimação e estabilidade para o regime, sobretudo no início de sua implantação.

O prefeito de Caruaru Drayton Nejaim foi um importante ator político nas relações de poder em tela. Atendendo ao dispositivo legal da CGI, ele foi acionado pela Comissão para apresentar formalmente as denúncias contra seus funcionários. Como mencionado anteriormente, dos doze inquéritos localizados, três eram de servidores públicos e três eram membros do Legislativo municipal. Jurandir Gonsalves era funcionário da prefeitura e, Manoel Messias e José Rabelo eram suplentes de vereadores no Legislativo municipal. Foi também na prefeitura municipal que a Comissão selecionou o maior número de testemunhas: cinco funcionários foram convocados e prestaram depoimentos na maior parte dos inquéritos localizados.

A Comissão também esteve envolvida com as relações de poder no Legislativo municipal. A Câmara de Vereadores de Caruaru teve alguns dos seus funcionários investigados pela Comissão de Investigação Sumária. No entanto, essa Casa não esperou pelos trabalhos da Comissão e começou, por conta própria, a efetuar sua "limpeza política" cassando os mandatos daqueles que consideravam subversivos. Em pleno sábado, dia 4 de abril de 1964, em sessão extraordinária, o Legislativo caruaruense votou o projeto de Resolução 91. Por meio dele, foram cassados os direitos políticos dos suplentes de vereador Manoel Messias e José Rabelo de Vasconcelos, eleitos em 1963 pelas legendas do Partido Republicano (PR) e do Partido Social Trabalhista (PST), respectivamente.

Na minuta do projeto de Resolução 91, o vereador Carlos Alberto Toscano de Carvalho, do PST, apresentou nos seguintes termos os motivos para as cassações: 
Justifica-se o presente projeto de Resolução no fato de que o Brasil, pela sua Constituição, não permite que seja a um brasileiro, considerado comunista fixado, ou pregador de ideias subversivas, concedido o direito de legislador, cujo propósito deve ser o de melhor servir à sua pátria ${ }^{9}$ (CARUARU, 1964, p. 01).

O texto finalizava revogando qualquer disposição em contrário. Ainda na mesma sessão, o vereador José Augusto de Araújo, do PSP, apresentou o requerimento de número 74, solicitando regime de urgência na votação do projeto de Resolução 91. Sua solicitação foi atendida e aprovada em plenário. Por conseguinte, no mesmo dia, o projeto foi apresentado, levado à votação e aprovado, resultando na cassação dos direitos políticos dos mencionados suplentes de vereadores. Essas ações demonstram que, antes mesmo de o Ato Institucional de 9 de abril ser decretado, as cassações já começaram a ser executadas contra aqueles considerados subversivos.

A Câmara de Vereadores de Caruaru continuou efetuando seus expurgos. Em 21 de dezembro de 1964, levou à votação o projeto de Resolução nº 100 para cassar os direitos políticos de Severino Rodrigues Sobrinho, que ocupava a função de vice-prefeito e era vereador eleito pelo Partido Republicano. Na justificativa do projeto de resolução, o vereador Carlos Toscano recorreu ao inquérito movido pela Comissão de Investigação Sumária contra o vice-prefeito, no qual foi enquadrado na Lei de Segurança Nacional por ter atentado, segundo aquela Comissão, contra a segurança do país, o regime democrático e a probidade administrativa. O inquérito ainda concluía, de acordo com Carlos Toscano, que tinha sido comprovada corrupção quando ele exercia o cargo de fiscal no Instituto de Aposentadorias e Pensões dos Ferroviários. Por conseguinte, encontrava-se justificada a cassação e perda dos mandatos de Severino Rodrigues.

Severino Rodrigues reagiu. Para reassumir os cargos suspensos, entrou com recurso no Tribunal de Justiça solicitando a anulação das medidas tomadas pelo Legislativo municipal. O recurso foi analisado e concedida razão para o pleiteante, conforme relatado em ata da Câmara Legislativa. A decisão do Tribunal de Justiça em

\footnotetext{
${ }^{9}$ Projeto de Resolução nº 91 . Câmara de Vereadores de Caruaru, 4 de abril de 1964. É importante registrar as disputas políticas vivenciadas dentro dos partidos. Existiam situações em que parlamentares vinculados a mesma sigla partidária, eram adversários políticos. Um exemplo foi a resolução elaborada pelo vereador Carlos Alberto Toscano de Carvalho para cassar os direitos políticos de um dos membros do seu próprio partido, o PST.
} 
favor de Severino Rodrigues provocou intensas discussões no Legislativo municipal. O vereador Antônio Bezerra do Amaral, do PST, em sessão extraordinária protestou veementemente contra a decisão do Ministério da Justiça que, no seu entender, significava grande constrangimento para o Legislativo municipal. Enfatizou ainda que aquela Casa não recuaria e que o Legislativo estava "pronto para cassar mais uma vez os mandatos de Severino Rodrigues Sobrinho" (CARUARU, 1965a, p. 5). Atitude também compartida pelo vereador José Augusto de Araújo, do PSP, para quem a decisão do Ministério da Justiça desmoralizava a Câmara de Vereadores.

Apesar dos embates e dos votos de protestos, a decisão judicial prevaleceu e, no dia 30 de abril de 1965, a Câmara de Vereadores aprovou a Resolução nº 89, cujo primeiro artigo versava: "ficam reintegrados os mandatos de vereador e Vice-Prefeito do Sr. Severino Rodrigues Sobrinho em atendimento à decisão da Justiça" (CARUARU, 1965b, p. 1) e no artigo segundo revogavam-se as disposições em contrário. De acordo com a historiadora Mariana Joffilly (2013), no início do regime, a posição da Justiça contrariando, inclusive, decisões militares, gerou muitos embates que a legislação repressiva a partir do Al-2 tentou resolver. De acordo com aquela historiadora, os decretos do $\mathrm{Al}-2$ representavam reivindicações de parte dos militares que desejavam maior rigor na punição dos crimes políticos, pois "estavam descontentes com o fato de muitos recursos judiciais terem permitido que parte dos indivíduos processados pelos IPM fosse liberada" (JOFFILLY, 2013, p. 28). Esses embates também tensionaram fortemente as relações entre o regime militar e o Supremo Tribunal Federal (STF), como demonstrou Felipe Recondo (2018).

As cassações ocorridas na Câmara de Vereadores possibilitam analisar como a repressão política implementada com o golpe foi apropriada e reproduzida por uma parcela dos vereadores. No entanto, nem sempre a Justiça atendia ou julgava favoravelmente as cassações aprovadas naquela Casa legislativa. Esses confrontos ou desacordos que também ocorriam entre as Assembleias Legislativas e a Justiça devem ter concorrido para a formulação do artigo 19 do Al-2. Em 27 de outubro de 1965, era decretado o Al-2, cujo artigo 19 decretava que ficavam excluídos da apreciação judicial "as resoluções das Assembleias Legislativas e Câmara de Vereadores que hajam cassado 
mandatos eletivos ou declarado o impedimento de governadores, deputados, prefeitos ou vereadores, a partir de 31 de março de 1964 até a promulgação deste Ato" (BRASIL, 1969, p. 14).

O referido artigo conferia significativo poder às Câmaras de Vereadores para executar suas cassações. Seus expurgos passavam a desfrutar da legalidade e dispensavam apreciação judicial. As cassações perpetradas nesses espaços precisam ser compreendidas, não apenas como decorrentes da vontade e poder de mando dos militares que ocupavam os principais cargos no regime ditatorial. Eram decisões que não representavam os desejos apenas dos militares, mas também e principalmente dos legisladores. As cassações, para serem sancionadas, dependiam da elaboração do projeto e da votação e, apenas quando aprovadas por maioria, permitia que os mandatos fossem cassados.

As cassações eram, portanto, executadas nas disputas políticas compartidas entre militares e vereadores. Se os militares eram os atores responsáveis pela criação e decretação dos artigos que compunham os Atos Institucionais, por exemplo, os vereadores não atuaram apenas como sujeitos coadjuvantes. Ocuparam o proscênio do palco e elaboraram os projetos de lei para cassar os pares que julgavam subversivos. Por conseguinte, as decisões tomadas pelos Legislativos, sejam na esfera federal, estadual ou municipal, não podem ser percebidas de forma simplória como decorrentes da vontade pura e simples dos militares. Em outros termos, as cassações dos vereadores foram decisões tomadas em primeiro lugar pelos membros de suas respectivas Câmaras. Entretanto, os expurgos faziam parte da política autoritária do regime militar. Ou seja, uma vez sancionadas as normas do Al-2, os cassados por subversão nos Legislativos não poderiam recorrer da decisão na Justiça.

\section{Atos de inquirir: as práticas de punição nos inquéritos da Comissão}

Inquérito e Inquisição desfrutam no Dicionário Aurélio de um significado conceitual comum. Ambos são sinônimos de "ato de inquirir" ${ }^{\circ}$. Nesse sentido - e apenas nesse - os

\footnotetext{
${ }^{10}$ Por certo que não estou unindo nem dissolvendo as inúmeras distinções entre os inquéritos movidos pela Comissão de Investigação Sumária e os praticados pelo tribunal eclesiástico através da Inquisição movida pela Igreja Católica.
} 
inquéritos movidos pela Comissão de Investigação Sumária desenvolveram práticas de inquisição na medida em que construíram um conjunto de ações punitivas por meio das investigações realizadas, dos processos produzidos, dos interrogatórios executados e das sanções aplicadas.

Além de servidores públicos, os inquéritos movidos pela Comissão de Investigação Sumária atingiram intelectuais, comerciantes, líderes sindicais e estudantes. Dos doze processos a que tive acesso, metade dos investigados não se enquadrava nos procedimentos que versavam nos artigos do Decreto 53.897. Tratava-se de pessoas sem vínculo com o serviço público. Eram lideranças políticas ligadas aos sindicatos existentes na cidade de Caruaru, como o sindicato dos sapateiros, dos padeiros e dos hoteleiros. Os processos dos investigados que não eram servidores públicos foram encaminhados para a Justiça Militar, servindo de fonte e provas para compor os IPMs que essa instância judicial abriu contra os acusados. Dos doze inquéritos localizados, cinco serviram de base documental para os IPMs abertos contra os investigados Manoel Messias, Francisco de Assis Claudino, Abdias Bastos Lé, José Rabelo e Ernesto Correia.

Uma vez encerrados os inquéritos, a Comissão lavrava os relatórios de conclusão em que expunha em quais artigos da Lei de Segurança Nacional os indiciados estavam enquadrados e, por extensão, a pena que deveriam cumprir mediante as sanções previstas nessa lei. Os desdobramentos seguintes competiam à Justiça Militar, como é possível perceber nos relatórios da Comissão e no próprio artigo $6^{\circ}$ do Decreto 53.897, quando versa sobre os procedimentos que a Comissão deveria tomar uma vez que fosse decidido aplicar alguma das sanções previstas na lei. Nesse sentido, a Justiça Militar foi fartamente alimentada pelos documentos produzidos pela Comissão de Investigação Sumária.

Pelas conclusões emitidas nos inquéritos, as possibilidades de os investigados serem absolvidos eram mínimas, ou quase inexistentes. De acordo com o Decreto 53.897, a defesa para os acusados consistia em permitir que eles apresentassem seus argumentos - oralmente ou por escrito - se ainda não o tivessem feito nos depoimentos. Para os que assim procederam não se alteraram as conclusões emitidas pelos relatores. 
No inquérito da Comissão de Investigação Sumária aberto contra Manoel Messias da Silva - principal liderança política representante das esquerdas na cidade -, ele era acusado de atentar contra a segurança do país. Por meio dos amigos Abdias Bastos Lé e Hugo Martins - lideranças comunistas no município -, ele começou a se inserir nas discussões políticas da época.

Na biblioteca municipal, espaço de encontros, debates e discussões políticas entre os jovens da cidade, Manoel Messias conheceu Romero de Figueiredo, filho de Henrique de Figueiredo, advogado e uns dos principais articulistas do jornal $A$ Vanguarda, além de Francisco de Assis Claudino, Arsênio Gomes, Ernesto Correia e Aluísio Falcão. Ele relembrou, em seus relatos de memória, que aquelas pessoas estavam ligadas direta ou indiretamente ao Partido Comunista e que o contato com elas permitiu que entendesse melhor as ideias e os princípios defendidos pelo comunismo (MONTENEGRO et al., 2012).

Para ele, as experiências vividas na biblioteca foram de significativa importância para aqueles jovens iniciarem suas lidas nas batalhas políticas da vida. Nas entrevistas realizadas com Francisco de Assis Claudino e Romero de Figueiredo, eles relembram com saudade e destacam as discussões efervescentes vividas em fins dos anos 1950 e início da década seguinte. Discussões e encontros que não passaram despercebidos pela vigilância do DOPS/PE.

De caráter confidencial, o Informe 73/17/ARE/83 apresentava Manoel Messias pelo nome, filiação, naturalidade e profissão. Esse era o modelo adotado nas fichas em que eram preenchidas as informações sobre os investigados. O que difere, nos documentos referentes a Manoel Messias, diz respeito à profissão. Alguns dos investigados pelo SNI receberam como profissão o acréscimo do adjetivo subversivo e a área de atuação. Dessa forma, constava como profissão de Messias estudante subversivo de Caruaru/PE.

Na primeira página dos informes do SNI apresenta-se, geralmente em um ou dois parágrafos, a pessoa sob investigação. Manoel Messias foi assim apresentado:

O nominado, elemento comunista, cuja área de atuação era o município de Caruaru/PE, em 1964 esteve preso e recolhido à Casa de Detenção, em Recife/PE, para averiguações de suas atividades subversivas. Em 1967 foi condenado a 14 anos de reclusão como incurso nos artigos $1^{\circ}, 9^{\circ}$ e 13 da Lei 1.802/53 - LSN (BRASIL, SNI, 1983, p. 1). 
A denúncia contra Manoel Messias resultou no processo de investigação sumária procedido na sede da Secretaria Assistente - da qual ele fazia parte no governo de Miguel Arraes como subsecretário com atuação em Caruaru -, que apurava atividades consideradas subversivas desenvolvidas naquele órgão. Dessa forma, Manoel Messias figurava como um dos indiciados por subversão ${ }^{11}$. O Ministério Público, por meio de seu representante - cujo nome não aparece no informe do SNI -, ofereceu denúncia contra ele enquadrando-o como infrator do artigo $2^{\circ}$, inciso III, da Lei 1.802. Em outras palavras, o Ministério Público estava acusando Manoel Messias de tentar mudar a ordem política e social estabelecida na Constituição, mediante ajuda de Estado estrangeiro, conforme o inciso III do artigo $2^{\circ}$ daquela lei, com pena de quinze a trinta anos para os líderes, ou "os cabeças", como aparece descrito na lei.

O Inquérito de Investigação Sumária contra Messias teve início oficialmente no dia 27 de abril de 1964. No entanto, os trabalhos da Comissão sobre ele antecederam essa data porque em 24 de abril, o Exército já tinha sido acionado e a $22^{\mathrm{a}} \mathrm{CR}$ (Circunscrição de Recrutamento) de Caruaru já havia preparado um informe com o histórico de Manoel Messias e encaminhado para a Comissão. Com base na ficha cadastral do acusado, o coronel Justo Moss Simões dos Reis, chefe da $22^{\mathrm{a}} \mathrm{CR}$, preparou um relatório informando que o indiciado era suspeito de praticar atividades comunistas em Caruaru, pois em 1959 foi preso, durante um movimento grevista, quando tentava desengatar um dos vagões de um trem com o objetivo de impedir que a locomotiva seguisse seu trajeto. Informou ainda que ele estava ligado a lideranças políticas na cidade, de proximidade notória com as ideias subversivas, como Celso Rodrigues e o sargento Severino Ferraz, bem como era assessor do então governador do Estado de Pernambuco, Miguel Arraes, deposto em abril de 1964 .

Contra os acusados e investigados pela Comissão, foram abertos inquéritos, e o Exército - por meio da $22^{\mathrm{a}} \mathrm{CR}$ - foi acionado não só para emitir pareceres com os

\footnotetext{
11 O processo movido pelo Ministério Público contra Manoel Messias, por sua vez, se respaldava nos documentos fornecidos, na grande maioria, pela Secretaria de Segurança Pública do Estado, resultantes, principalmente, do inquérito movido pela Comissão de Investigação Sumária. Nos antecedentes arrolados no histórico do indiciado em tela, encontramos as folhas em papel timbrado e com a logomarca daquela instituição, bem como da Sétima Região Militar e do IV Exército, conforme as informações registradas no inquérito pela Comissão de Investigação Sumária.
} 
históricos dos indiciados, como também para selecionar as testemunhas e colher informações através dos depoimentos. Uma das testemunhas, estrategicamente selecionada pelo chefe da $22^{\text {a }} \mathrm{CR}$ e pelo presidente da Comissão de Investigação Sumária, teria afirmado que "Manoel Messias e outros comunistas eram elementos perigosos, atuantes, que faziam publicamente propaganda de processos violentos para a subversão da ordem política; que os referidos comunistas promoviam e incentivavam greves"(Comissão de Investigação Sumária, 1964. SSP/DOPS/APEJE. Prontuário Individual $\left.\mathrm{n}^{\circ} 1.208, \mathrm{~s} / \mathrm{p}\right)^{12}$. Esse testemunho colhido nas instalações do Exército em Caruaru foi uma das diversas provas produzidas pela Comissão de Investigação Sumária para o processo contra o indiciado.

No dia 27 de abril de 1964, José de Barros Filho, cobrador do sindicato dos feirantes de Caruaru, era oficialmente convidado a comparecer no dia seguinte para prestar depoimento na $22^{\mathrm{a}} \mathrm{CR}$ de Caruaru. Assim, aos 28 dias do mês de abril de 1964, o Termo de Declaração prestado por José de Barros Filho foi assinado por ele, pelo promotor público, presidente da Comissão, Valter Rodrigues da Rosa Borges, além do capitão do Exército e do segundo sargento na função de escrivão. De acordo com o escrivão, o declarante conhecia o indiciado e o reconhecia como agitador comunista atuante em Caruaru.

No dia seguinte, nas instalações do Exército em Caruaru, era produzido mais um Termo de Declaração para o inquérito. Dessa vez, o funcionário da prefeitura Wilson Mendes da Silva prestava seu testemunho perante a Comissão de Investigação Sumária, no dia 29 de abril de 1964. De acordo com o Termo de Declaração, a testemunha conhecia o indiciado e poderia afirmar ter sido Manoel Messias um dos líderes do movimento subversivo em Caruaru, principalmente por ser homem de confiança do ex-governador Miguel Arraes. Segundo o escrivão, o declarante informava que "Manoel Messias fazia publicamente pregações revolucionárias e difundia, por todos os meios, a doutrina marxista e era, portanto, um dos elementos mais perigosos, no plano agitacionista do município de Caruaru" (Idem).

\footnotetext{
${ }^{12}$ Os documentos que compõem os Inquéritos de Investigação não são paginados. Para as demais citações dos documentos do inquérito movido contra Manoel Messias, usarei as iniciais do Prontuário Individual (PI) e seu respectivo número de identificação.
} 
No testemunho de Wilson Mendes se destacava a existência de um movimento subversivo em Caruaru que vinha promovendo agitações e perturbando a ordem pública, como foi possível perceber nas greves promovidas pelos comunistas locais, como a que ocorreu contra a prefeitura, na qual o acusado teria comandado o movimento paredista. Sendo o declarante funcionário daquele órgão, ele se portava como alguém que tinha conhecimento de causa para o que estava relatando.

A terceira testemunha a depor contra Manoel Messias reafirmou as acusações dos que a antecederam. Em 30 de abril de 1964, também nas dependências do Exército em Caruaru, outro funcionário da prefeitura, Arnaldo Ferreira da Silva, era ouvido pela Comissão de Investigação Sumária. Segundo o escrivão, o declarante confirmava a existência de um movimento subversivo em Caruaru por meio de comícios, palestras, passeatas e greves, preparados abertamente pelos comunistas da cidade, principalmente por Manoel Messias. Arnaldo Ferreira acrescentou outra informação. Segundo o registro do escrivão, na noite 31 de março de 1964, ocorreu uma reunião na delegacia de polícia, local cujo objetivo era organizar um movimento de resistência e defesa do governo deposto e que Manoel Messias teria sido o líder dessa reunião, em que também teria planejado a "invasão" à prefeitura, junto com outros comunistas.

As acusações narradas se repetiam nos testemunhos. No entanto, para a Comissão, essa repetição servia de prova de autenticidade para os depoimentos. Significava que os declarantes não estavam prestando falsos testemunhos, porque o discurso de um era percebido e confirmado no depoimento do outro. As testemunhas, portanto, não apresentavam contradições em seus relatos. Por conseguinte, a repetição tinha poder de autoridade.

O que teria dito Manoel Messias da Silva diante daquelas acusações? Ele foi intimado a prestar depoimento perante a Comissão. "Ele confessa com uma frieza de estarrecer, somente admissível aos absolutamente convictos às ideias marxistas, que não somente se limitava a professá-las, mas a difundi-las, quer atrave $z^{13}$ de comícios, quer diretamente em aulas, doutrinando um grupo de estudantes" ( $\left.P I n^{\circ} 1.208\right)$. É com essas

\footnotetext{
${ }^{13}$ Optei por manter a grafia como se encontra no documento.
} 
palavras que o redator do inquérito inicia um dos relatórios de conclusão, depois de mencionar que, como prova, bastaria a confissão do indiciado por ser "'a rainha de todas as provas"” (idem).

O relator escreveu que Manoel Messias teria confessado as denúncias que lhe eram feitas. Teria afirmado que mantinha relações com "elementos de esquerda, estando principalmente vinculado à política de Miguel Arraes; que ele, indiciado, era sim, ideologicamente, um homem de esquerda, e sua atividade se orientava no sentido de pregações e doutrinações realizadas através de comícios (idem)”.

Não sabemos se essas foram as palavras usadas por Manoel Messias para responder às perguntas do presidente da Comissão de Investigação. Sua assinatura ao final do depoimento está longe de significar anuência às palavras transcritas pelo relator. Neste sentido, a historiadora Mariana Joffilly oferece importantes análises sobre a dinâmica constitutiva dos interrogatórios. Ao estudar a Operação Bandeirante e o DOI em São Paulo, ela destaca que "no ato da transcrição, a escuta da fala do depoente é atravessada pela percepção dos interrogadores. As diversas operações envolvidas na produção do depoimento revelam indícios de como o órgão constrói uma visão dos fatos narrados pelo interrogado" (JOFFYLLY, 2013, p. 122).

Importante também destacar que, sendo a transcrição do escrivão e o relato oral prestado pelo depoente de ordens distintas, não necessariamente se negam ou se excluem. Ou seja, não implica dizer que Manoel Messias tenha negado que era de esquerda, ou que não estava ligado à política de Miguel Arraes. Mas tão somente que as palavras às quais temos acesso no inquérito foram resultantes das lentes políticas do relator, para representar em grafia os testemunhos orais prestados pelo depoente.

Essa distinção é, do meu ponto de vista, importante porque se trata de dois universos diferentes, por mais próximos e interconectados que estivessem. A assinatura de Manoel Messias, ou de qualquer outro depoente, - ainda mais quando este se encontra no lugar do acusado sob interrogatório - não pode ser pensada como termo de concordância irrestrita entre o texto escrito e a fala do testemunho. São de naturezas distintas. A maneira de narrar, bem como a escolha de cada palavra, é indicativa da 
percepção daquele que escreve, assim como apresenta as intenções para as quais se destina e para quem se direciona a escrita.

Outro fator, não menos importante, diz respeito às condições de produção daquele - e de tantos outros - testemunho. Não raro, os depoimentos eram produzidos sob tortura. O jornalista Marcio Moreira Alves, em seu livro Torturas e torturados, apresentou um panorama detalhado sobre as práticas de tortura que estavam ocorrendo no Recife, de acordo com as denúncias que vinham surgindo. Esse autor entrevistou Manoel Messias, que na época Ihe informou que "foi espancado pelo coronel Justo Moss e pelo capitão Gondim, de tal forma que teve que receber tratamento, que lhe foi prestado pelo Dr. Honório Florença, do SAMDU” (ALVES, 1966, p. 55).

Nesse sentido, essas condições de produção dos testemunhos poderiam em última instância condicionar as respostas nos interrogatórios, as quais o escrivão grafava em papel o conteúdo que temos acesso nos inquéritos. Em outras palavras, o que se encontra registrado nos autos de interrogatórios pode muito bem esconder a dor, o sangue e o medo sob os quais se produziam os depoimentos. Como relatou Marcio Moreira Alves (1966), respaldado nos laudos médicos a que teve acesso, muitas torturas estavam ocorrendo em Pernambuco naquele momento. O presidente Castelo Branco chegou a mobilizar uma Comissão e a enviou a Pernambuco para investigar as procedências das denúncias sobre as torturas, conforme ressalta Montenegro (2012).

Dos registros do escrivão emerge um Manoel Messias que se encontrava em uma ampla e complexa rede de relações com o comunismo. Segundo o relator, o depoente confessou que esteve na Rússia em 1961, fazendo parte de uma delegação de estudantes cujo objetivo da viagem tinha fins culturais. Que a ida à Rússia lhe proporcionou um intercâmbio cultural, certamente, não se pode negar. No entanto, nas circunstâncias em que aquelas palavras foram produzidas, sua ida a Moscou produziu outros significados.

Essa confissão passou a ser interpretada como demonstração da influência do comunismo internacional na vida política da cidade, do Estado e do país, e por extensão, do envolvimento do indiciado com a trama subversiva das ideias vermelhas - como se referiam algumas autoridades - de caráter internacional. Essa leitura era reforçada à 
medida que o depoente teria afirmado no Ato de Interrogatório, que, durante sua estada na Europa, tinha visitado outros países comunistas, como a Tchecoslováquia e a Alemanha Oriental, conforme expressou no ato de interrogatório.

A estada de Manoel Messias pelos países comunistas teria contribuído para o estabelecimento de contatos com políticos e intelectuais que passaram a enviar uma significativa quantidade de revistas e livros, que eram vendidos na barraca Yuri Gagarin ${ }^{14}$. Por esse ângulo de percepção, o envolvimento dele com o comunismo internacional deixava de ser uma realidade distante sem desdobramentos com a vida cotidiana da cidade, passando a interferir, portanto, nas relações políticas e sociais praticadas no município.

\section{Considerações finais}

Os órgãos de segurança - com a colaboração direta dos órgãos de informação foram agentes produtores das mais diversas práticas de vigilância, perseguição, repressão, torturas e mortes executadas durante a ditadura militar. Como demonstram as pesquisas de Antony Pereira (2010) e Carlos Fico (2001 e 2012), criam as condições para pôr em cena um estado de exceção alterando radicalmente as relações cotidianas de milhares de cidadãos civis. Concorreram como força potencial para a construção e execução das condições políticas para investigar, processar, prender, torturar e até matar seus oponentes políticos. Por meio da vigilância sistematizada, das perseguições desenvolvidas e das investigações realizadas, aqueles órgãos modificaram a vida de

\footnotetext{
${ }^{14}$ A barraca de jornais e revista Yuri Gagarin foi um espaço de luta, em Caruaru-PE, para aqueles que defendiam as ideias de esquerda, por mais polifônicas que fossem. Foi um espaço de produção e de circulação do saber, de encontros para uma parcela de jovens, estudantes e literatos caruaruenses na década de 1960. Localizava-se no centro da cidade, ao lado da igreja matriz e despertou sentimentos de quem defendia e daqueles que a combatiam. Romero de Figueiredo, hoje artista plástico aposentado, líder comunista em Caruaru na época, relembrou na entrevista as experiências marcantes em torno da barraca Yuri Gagarin: "Yuri Gagarin, a barraca! Era toda azul porque Gagarin falou que a terra era azul, né? A gente pintou a barraquinha de azul, o nome vermelho Yuri Gagarin. Começamos a vender jornais do sul do país; era Novos Rumos, O Semanário, eram jornais da cidade também, revistas, livros... transformamos a barraquinha numa livrariazinha, num encontro da juventude" (CAVALCANTI, 2017, p. 138). Assim, por meio da barraca, os comunistas se faziam presentes no centro político-urbano-geográfico da cidade. Era, portanto, uma estratégia de luta a escolha daquele espaço. Sua presença constituía um símbolo da resistência dos comunistas e representava a demarcação de um território nas relações de forças ali praticadas. Era uma estratégia política para se fazer presente nas relações de poder.
} 
dezenas de pessoas e interferiram de forma significativa no reordenamento das relações políticas, sociais e culturais. Suas ações se constituíram como força potencial, como instrumento de controle político, concorrendo como força agenciadora capaz de alterar as relações sociais.

Por esse ângulo de percepção, a Comissão de Investigação Sumária se institui como uma poderosa e importante ferramenta política nas disputas que concorreram para justificar, executar e legitimar a ditadura instaurada pelos militares em 1964. Por conseguinte, a criação da Comissão, os inquéritos abertos, as investigações desenvolvidas e as sentenças lavradas deixavam uma importante lição: os cidadãos não estavam livres da possibilidade de serem investigados por ela, bem como, uma vez sendo investigados, não havia mecanismo para recorrer das sentenças nas instâncias judiciais. As provas produzidas para os inquéritos - sobretudo os depoimentos das testemunhas estrategicamente escolhidas -, e usadas para emitir as sentenças, indicavam que o objetivo era a cassação e a condenação dos cidadãos que se posicionavam contrariamente ao regime ditatorial. Por conseguinte, as condenações decretadas demonstravam que as garantias constitucionais tinham sido abolidas e as condenações sumárias passaram a se constituir como política de Estado.

\section{Referências}

ALVES, Marcio Moreira. Torturas e torturados. Rio de Janeiro: Editora Idade Nova, 1966.

BRASIL. Ministério da Aeronáutica. Atos da Revolução de 1964. Brasília: Força Aérea Brasileira, 1969. Coletânea preparada pelo Ministério da Aeronáutica.

BRASIL. Comissão de Investigação Sumária, 1964b. Inquéritos movidos pela Comissão Geral de Investigação.

BRASIL. Sistema Nacional de Informação, 1983. 
BORGES, Nilson. A Doutrina de Segurança Nacional e os governos militares. In: FERREIRA, Jorge; DELGADO, Lucilia de Almeida Neves (Orgs.). O Brasil Republicano: vol. 4: o tempo da ditadura: regime militar e movimentos sociais em fins do século XX. 5. ed. Rio de Janeiro: Civilização Brasileira, 2012.

CARUARU. Resolução n 91, de 4 de abril de 1964. Câmara Municipal de Vereadores de Caruaru.

\section{CARUARU. Sessão Solene da Câmara dos Vereadores de Caruaru, 1965a. Atas [...]} Caruaru: s.n., 20 abr.1965.

CARUARU. Resolução nº 89 de 30 de abril de 1965. Câmara de Vereadores de Caruaru 1965b.

CAVALCANTI, Erinaldo Vicente. Ditadura militar no Brasil: entre práticas e representações. Rio de Janeiro e Recife: FGV e EdUFPE, 2017.

CAVALCANTI, Erinaldo Vicente. Crônica, história e política em tempos de Ditadura militar: embates e combates no Campo da escrita (PE, 1960-1968). Revista de História e Estudo Culturais, v. 15, n. 2, jul/dez, 2018.

CHIRIO, Maud. A política nos quartéis: revoltas e protestos de oficiais na ditadura militar brasileira. Rio de Janeiro: Zahar, 2012.

D'ARAUJO, Maria Celina; SOARES, Gláucio Ary Dillon; CASTRO, Celso (Orgs.). Visões do golpe: a memória militar sobre 1964. Rio de Janeiro: Relume-Dumará, 1994a.

D’ARAUJO, Maria Celina; SOARES, Gláucio Ary Dillon; CASTRO, Celso (Orgs.). Os anos de chumbo: a memória militar sobre a repressão. Rio de Janeiro: Relume-Dumará, 1994b.

FERREIRA, Jorge; GOMES, Ângela de Castro. 1964: o golpe que derrubou um presidente, pôs fim ao regime democrático e instituiu a ditadura no Brasil. Rio de Janeiro: Civilização Brasileira, 2014.

FICO, Carlos. Como eles agiam: Os subterrâneos da ditadura militar: espionagem e polícia política. Rio de Janeiro: Record, 2001.

FICO, Carlos. Espionagem, polícia política, censura e propaganda: os pilares básicos da repressão. In: FERREIRA, Jorge; DELGADO, Lucilia de Almeida Neves (Orgs.). O Brasil

Republicano: vol. 4: o tempo da ditadura: regime militar e movimentos sociais em fins do século XX. 5. ed. Rio de Janeiro: Civilização Brasileira, 2012.

FOUCAULT, Michel. Vigiar e punir: história da violência nas prisões. Petrópolis: Vozes, 2007. 
JOFFILLY, Mariana. No centro da engrenagem: os interrogatórios na Operação Bandeirante e no DOI de São Paulo (1969-1975). Rio de Janeiro: Arquivo Nacional; São Paulo: Edusp, 2013.

MONTENEGRO, Antonio Torres. História, metodologia, memória. São Paulo: Contexto, 2010.

MONTENEGRO, Antonio Torres Ligas camponesas e sindicatos rurais em tempo de revolução. In: FERREIRA, Jorge; DELGADO, Lucilia de Almeida Neves (Orgs.). O Brasil Republicano: vol. 3: o tempo da experiência democrática: da democratização de 1945 ao golpe civil-militar de 1964. 5 ed. Rio de Janeiro: Civilização Brasileira, 2003.

MONTENEGRO, Antonio T.; RODEGHERO, Carla S.; ARAÚJO, Maria Paula (Orgs.). Marcas da memória: história oral da anistia no Brasil. Recife: Editora Universitária da UFPE, 2012.

MOTTA, Rodrigo Patto Sá; REIS, Daniel Aarão; RIDENTE, Marcelo; MOTTA, Rodrigo Patto Sá (Orgs.). A ditadura que mudou o Brasil: 50 anos do golpe de 1964. Rio de Janeiro: Zahar, 2014.

MOTTA, Rodrigo Patto Sá; REIS, Daniel Aarão; RIDENTE, Marcelo; MOTTA, Rodrigo Patto Sá (Orgs.). O anticomunismo militar. In: MARTINS FILHO, João Roberto. O golpe de 1964 e o regime militar. São Carlos, SP: EdUFSCar, 2006.

MOTTA, Rodrigo Patto Sá; REIS, Daniel Aarão; RIDENTE, Marcelo; MOTTA, Rodrigo Patto Sá (Orgs.). Em guarda contra o perigo vermelho: o anticomunismo no Brasil (1917-1964). São Paulo: Perspectiva/Fapesp, 2002.

NUNES, Paulo Giovani Antonino. Golpe civil-militar e repressão no imediato pós-golpe em Minas Gerais. Cadernos do Tempo Presente. Revista Interdisciplinar de História. Grupo de Estudos do Tempo Presente-UFS, n. 12, 10 jun. 2013.

PEREIRA, Anthony W. Ditadura e repressão: o autoritarismo e o Estado de direito no Brasil, no Chile e na Argentina. São Paulo: Paz e Terra, 2010.

PORFÍRIO, Pablo F. A. Medo, comunismo e revolução: Pernambuco (1959-1964). Recife: Editora da UFPE, 2009.

RECONDO, Felipe. Tanques e togas: o STF e a ditadura militar. São Paulo: Companhias das Letras, 2018.

REZENDE, Maria José de. A ditadura militar no Brasil: repressão e pretensão de legitimidade 1964-1985. Londrina, PR: EDUEL, 2013.

SILVA, Marcília Gama da. Informação, repressão e memória: a construção do estado de exceção no Brasil na perspectiva do Dops-PE (1964-1985). Recife: Editora UFPE, 2014. 
Recebido em 11/02/2019 Aprovado em 27/06/2019

Universidade do Estado de Santa Catarina - UDESC Programa de Pós-Graduação em História - PPGH Revista Tempo e Argumento Volume 11 - Número 28 - Ano 2019 tempoeargumento@gmail.com 